\title{
Concentration and Separation of Active Proteins from Potato Industry Waste Based on Low-Temperature Evaporation and Ethanol Precipitation
}

\author{
Sanna Taskila, Mikko Ahokas, Juho Järvinen, Juho Toivanen, and Juha P. Tanskanen \\ Faculty of Technology, Chemical Process Engineering Unit, University of Oulu, P.O. Box 4200, 90014 Oulu, Finland \\ Correspondence should be addressed to Sanna Taskila; sanna.taskila@oulu.fi
}

Received 15 August 2016; Revised 12 January 2017; Accepted 24 January 2017; Published 19 February 2017

Academic Editor: Juan Manuel Ruiz-Lozano

Copyright (C) 2017 Sanna Taskila et al. This is an open access article distributed under the Creative Commons Attribution License, which permits unrestricted use, distribution, and reproduction in any medium, provided the original work is properly cited.

Purpose. Potato fruit juice, a residue of starch industry, contains up to $2.5 \%$ [w/w] of proteins that are potentially valuable rawmaterials of food, cosmetic, and pharma industries. The recovery of protein from the potato fruit juice is limited by the lack of industrially feasible concentration and separation technologies. The present research thus aimed at development of such process for the separation of active protease inhibitors from potato fruit juice. Methods. Low temperature mechanical vapor recompression evaporation was applied for concentration of potato fruit juice followed by ethanol precipitation for recovery of active proteins. The effects of precipitation temperature and precipitative agents were investigated employing response surface modeling methodology. Results. Concentration of potato fruit juice by evaporation was successful without loss of trypsin inhibition activity. Precipitation using $6.5 \mathrm{M}$ ethanol at low temperature $\left(0-+4^{\circ} \mathrm{C}\right)$ was found suitable for the recovery of active protease inhibitors from the concentrate. Piloting at starch industry yielded $50 \%$ of total proteins, with a high quantity of active protease inhibitors and a minor inclusion of other proteins. Conclusion. Concentration by low-temperature evaporation, followed by ethanol precipitation of protease inhibitors at optimized temperature, is an attractive option for valorization of potato fruit juice.

\section{Introduction}

Potato is a worldwide cultivated agricultural product, with global annual production of over 350 million tons. A remarkable quantity of those potatoes is used in starch industry leading to formation of potato fruit juice $(\mathrm{PFJ})$ as a side stream of starch extraction $[1,2]$. The high waste treatment costs have led to an active search of alternatives that would allow value creation from PFJ. Particularly potato proteins, accounting to approximately $2.5 \%(\mathrm{v} / \mathrm{v})$ of PFJ, are of special interest. Depending on the plant variety and growing conditions, potato contains ca. $10 \mathrm{~g} / \mathrm{kg}$ of proteins. In case of starch industry, the majority of those proteins end up into the PFJ.

The protein fractions of potato are considered to be nutritionally comparable to that of a whole egg, contributing to the high nutritional potential of the PFJ as well [3]. The main types of potato proteins are patatin, protease inhibitors (PIs), and other higher molecular weight proteins with sizes of $39-45,4-25$, and $30-40 \mathrm{kDa}$, respectively [3-5].
PIs, representing approximately $50 \%$ of potato proteins, have inhibitory activity against serine proteases, cysteine proteases, aspartate proteases, and metalloproteases [6]. The most abundant PIs of potato, denoted as potato serine protease inhibitor, that is, PSPI, possess high inhibitory activity on trypsin and chymotrypsin. PIs have been suggested to affect appetite control system in humans [7]. They are thus mainly considered useful as antinutritional agents. Potato PIs have also proven effects on skin diseases [8], and they may have the ability to lower blood pressure $[9,10]$.

The separation of proteins from PFJ is traditionally conducted under severe conditions, such as high temperatures or acidity, leading to coagulation and denaturation of proteins. Although coagulation is an effective means to remove proteins from dilute solution, it may also induce irreversible structural changes in the protein molecules, leading to loss of enzymatic activity. Milder technologies are thus needed to allow high-yield recovery of active potato proteins. 
Precipitation has been shown to be applicable for the separation of active proteins from PFJ in several earlier studies [5, $11,12]$. The selection of precipitation agent affects largely the yield of active potato proteins. $\left(\mathrm{NH}_{4}\right)_{2} \mathrm{SO}_{4}$ precipitation may be the most effective means to purify patatin while keeping its lipid acyl hydrolase activity [12]. Ferric chloride $\left(\mathrm{FeCl}_{3}\right)$ has been effective for the isolation of larger than $15 \mathrm{kDa}$ sized protease inhibitors [12]. Metal salts, such as $\mathrm{FeCl}_{3}$, act as precipitants disrupting the hydration barriers around the protein molecules. Without the hydration barrier the proteins interact with each other easier causing the formation of aggregates, which will then precipitate from the solution. $\mathrm{FeCl}_{3}$ also interacts with the polyphenols. Its role, however, is more of a competitive one since it forms complexes with proteins and also with the polyphenols leaving less polyphenols to interact with proteins [5].

Ethanol is also often used as a precipitation agent as it is miscible with water and thus a poor solvent for proteins. As a nonsolvent, it also has a lower dielectric point than water, increasing the protein-protein attraction forces. Ethanol is also able to form a solution with water, leaving less water to interact with the protein. This is similar to the mechanics involved in the salting-out method. As a commonly used precipitation agent ethanol is known to remain the activity of proteins, which means that it is safe to use with proteins products with conformity.

The present precipitation processes are also limited by the low concentration of proteins in PFJ, namely, $1-3 \%$ [1]. The recovery of active proteins without preliminary concentration is thus rather resource-efficient with high chemical consumption and large processing volumes. The objective of present research was thus to develop an energy and material efficient process that would be applicable for the recovery of active PIs from dilute PFJ produced in starch industry. The scope was on scalable technologies that allow high yield of active proteins without excessive chemical or energy consumption and high processing capacity and avoid need for extensive down-stream processing. For this purpose, a procedure involving MVR evaporation at mild conditions for the concentration of PFJ, followed by ethanol precipitation of protein at low temperature, is proposed.

\section{Material and Methods}

2.1. PFJ Concentrates. PFJ samples for initial precipitation experiments were prepared from commercial potatoes (cultivar Challenger) as described in previous studies [5]. Briefly, peeled potatoes were first ground in water with a domestic appliance grade blender, after which the potato solids were sieved out ending up with the PFJ. Industrial PFJ samples from a cooperating starch producer were also used for the confirmation of the viability of the concentration and recovery technology.

The in-house produced PFJ was concentrated by evaporation at $40^{\circ} \mathrm{C}$ and $35 \mathrm{mbar}$ for removal of excess water (laboratory scale equipment, Büchi Rotavapor R-153, and Büchi Vacuum System B-178). The industrial PFJ samples were concentrated in situ using pilot-scale single-state falling film mechanical vapor recompression (MVR) evaporation equipment (Epcon Evaporation Technology AS, Norway). The processing capacity of pilot-scale evaporation was $100 \mathrm{~L} / \mathrm{h}$ of PFJ. In MVR evaporation technology the vapor is compressed in a fan or a compressor to a higher temperature and pressure and used as energy source instead of boiler steam, leading to reasonably lower energy consumption for the water purification process (based on our experience 10$\left.25 \mathrm{kWh} / \mathrm{m}^{3}\right)$.

\subsection{Design of Experiments and Response Surface Modeling.} Response surface methodology (RSM) using MODDE software for Design of Experiments and Optimization (Version 8.0.0.0, UMETRICS AB, Umeå, Sweden) was applied for the modeling of factor effects on recovered activity of PIs. The RSM was prepared using quadratic face centered central composite design (CCF). The performances of the models were evaluated by assessing analysis of variance (ANOVA) as described in [13]. Briefly, with good models, the standard deviation of the model should be much larger than the standard deviation of the noise with its upper confidence level. The effect of a factor can be considered statistically significant if the confidence interval is not larger than the effect itself. Factors under investigation were ethanol concentration ( 0 6.5 M), $\mathrm{FeCl}_{3}$ concentration $(0-25 \mathrm{mM})$, and temperature $\left(0-20^{\circ} \mathrm{C}\right)$. The experiment matrix is presented in Table 1. The iteration algorithm for optimization was Nelder-Mead method [14].

2.3. Precipitation. The initial development of precipitation process was carried out in total volume of $3 \mathrm{~mL}$. Precipitation agents and $170 \mathrm{~g} / \mathrm{l}$ of PFJ were added to each reaction according to Table 1. With the ferric chloride EDTA was added to the resolubilization buffer to inhibit the effect of the metal ions' charge on the dissolving of the proteins to the liquid [5]. Reactions were incubated under agitation in Thermomixer Comfort (Eppendorf, Germany) for $1 \mathrm{~h}$. After precipitation the reactions were centrifuged at $11000 \times \mathrm{g}$ and $+4^{\circ} \mathrm{C}$ to recover precipitated proteins. Active proteins were recovered by dissolving to $100 \mathrm{mM}$ sodium phosphate buffer ( $\mathrm{pH} \mathrm{7.0)}$ and incubation at $20^{\circ} \mathrm{C}$ and $400 \mathrm{rpm}$ for $1 \mathrm{~h}$. Nonsoluble fraction was removed by centrifugation. The precipitation experiments of PFJ concentrates from starch industry were carried out by addition of $1 \mathrm{~L}$ of $96 \%$ ethanol to $1 \mathrm{~L}$ of PFJ concentrate $\left(48 \%\right.$ ethanol) at $+4^{\circ} \mathrm{C}$.

2.4. Protein Quantity and Quality Analyses. Sodium dodecyl sulphate polyacrylamide gel electrophoresis (SDS-PAGE) was used for the control of produced protein fractions. PageRuler ${ }^{\mathrm{TM}}$ Plus Prestained Protein Ladder (Thermo Scientific) was used as marker in SDS-PAGE. The total protein content was measured by means of standard BCA assay (The Thermo Scientific Pierce BCA Protein Assay Kit).

2.5. Protease Inhibitor Activity Measurement. The solubility of potato proteins correlates to the structure of potato proteins; that is, irreversible structural changes induced during the precipitation show poor resolubility of the protein from the precipitate. Thus the resoluble protein yield can be used as 


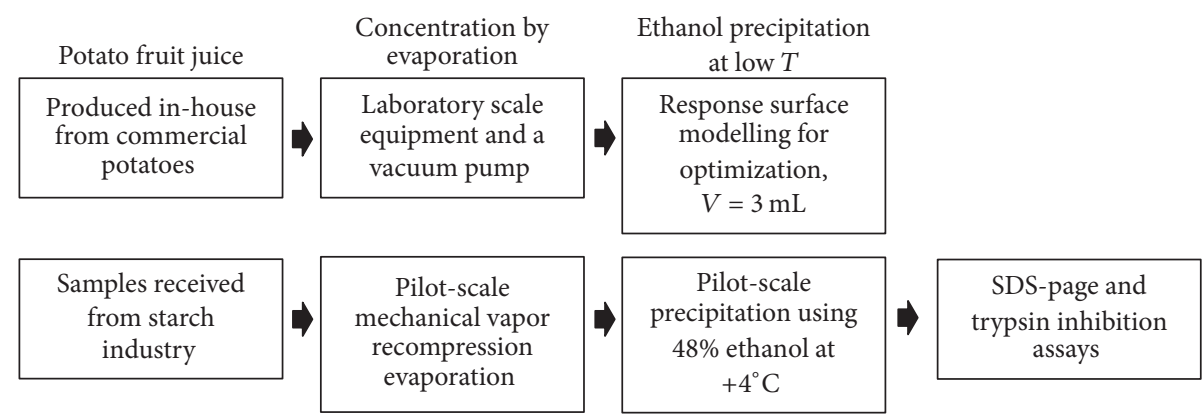

FIGURE 1: Experimental procedures in the present research. The upper row represents the procedure to optimize the precipitation conditions using commercial potatoes. The lower row represents the procedure to utilize optimized conditions at starch industry for the pilot-scale precipitation.

TABLE 1: Experiment matrix for RSM.

\begin{tabular}{lcccc}
\hline Exp number & Exp name & $\mathrm{EtOH}[\mathrm{M}]$ & $\mathrm{FeCl}_{3}[\mathrm{mM}]$ & $T\left[{ }^{\circ} \mathrm{C}\right]$ \\
\hline 1 & $\mathrm{~N} 1$ & 0 & 0 & 0 \\
2 & $\mathrm{~N} 2$ & 6.5 & 0 & 20 \\
3 & $\mathrm{~N} 3$ & 0 & 0 & 20 \\
4 & $\mathrm{~N} 4$ & 0 & 25 & 0 \\
5 & $\mathrm{~N} 5$ & 3.25 & 0 & 10 \\
6 & $\mathrm{~N} 6$ & 3.25 & 12.5 & 10 \\
7 & $\mathrm{~N} 7$ & 3.25 & 25 & 10 \\
8 & $\mathrm{~N} 8$ & 3.25 & 25 & 20 \\
9 & $\mathrm{~N} 9$ & 0 & 25 & 20 \\
10 & $\mathrm{~N} 10$ & 6.5 & 12.5 & 10 \\
11 & $\mathrm{~N} 11$ & 6.5 & 25 & 0 \\
12 & $\mathrm{~N} 12$ & 0 & 12.5 & 10 \\
13 & $\mathrm{~N} 13$ & 6.5 & 0 & 0 \\
14 & $\mathrm{~N} 14$ & 3.25 & 12.5 & 10 \\
15 & $\mathrm{~N} 15$ & 6.5 & 25 & 20 \\
16 & $\mathrm{~N} 16$ & 3.25 & 12.5 & 0 \\
17 & $\mathrm{~N} 17$ & 3.25 & 12.5 & 20 \\
18 & $\mathrm{~N} 18$ & 3.25 & 12.5 & 10 \\
\hline
\end{tabular}

a measure for recovery of active proteins [15]. Moreover, the resoluble protein yield can be quantitatively determined. Therefore, the quantity of the resoluble proteins was used for the evaluation of active protein yields. However, to verify that the activity of PIs is remained during processing, trypsin inhibition assay was prepared. Trypsin disintegrates methyl ester of $\mathrm{N}-\alpha$-tosyl-L-arginine (TAME, extinction coefficient $449.5 \mathrm{l} / \mathrm{mol} * \mathrm{~cm}$ ). Disintegration can be detected with spectrophotometer at $247 \mathrm{~nm}$ (UV). In order to determine trypsin inhibition activity in the isolated protein fractions, the samples were first diluted to reach total protein concentration of approximately $2-4 \mathrm{~g} / \mathrm{l}$.

The experimental procedures are summarized in Figure 1.

\section{Results}

3.1. Effect of Precipitation Agents and Temperature on Protein Recovery from PFJ. Effects of ethanol, $\mathrm{FeCl}_{3}$, and temperature
TABLE 2: Resoluble protein concentration in precipitates.

\begin{tabular}{lcc}
\hline Exp number & Variable levels $\left[\mathrm{EtOH} / \mathrm{FeCl}_{3} / \mathrm{T}\right]$ & Protein $[\mathrm{g} / \mathrm{L}]$ \\
\hline 1 & $0 / 0 / 0$ & 14.25 \\
2 & $6.5 / 0 / 20$ & 5.80 \\
3 & $0 / 0 / 20$ & 37.47 \\
4 & $0 / 25 / 0$ & 29.76 \\
5 & $3.25 / 0 / 10$ & 24.13 \\
6 & $3.25 / 12.5 / 10$ & 10.08 \\
7 & $3.25 / 25 / 10$ & 17.35 \\
8 & $3.25 / 25 / 20$ & 13.25 \\
9 & $0 / 25 / 20$ & 29.08 \\
10 & $6.5 / 12.5 / 10$ & 25.21 \\
11 & $6.5 / 25 / 0$ & 8.75 \\
12 & $0 / 12.5 / 10$ & 22.31 \\
13 & $6.5 / 0 / 0$ & 10.35 \\
14 & $3.25 / 12.5 / 10$ & 13.11 \\
15 & $6.5 / 25 / 20$ & 16.89 \\
16 & $3.25 / 12.5 / 0$ & 16.32 \\
17 & $3.25 / 12.5 / 20$ & 16.94 \\
18 & $3.25 / 12.5 / 10$ & 19.76 \\
\hline
\end{tabular}

on yield of resoluble potato PIs from laboratory prepared PFJ were investigated by means of RSM. Resoluble protein concentrations recovered in precipitation are presented in Table 2. To improve fit of model response transformation was used as described in [13]. According to $F$-test, levels of ethanol and temperature affected yield of resoluble potato proteins $(p<0.05$, Figure 2$)$. The effect of $\mathrm{FeCl}_{3}$ was not statistically significant.

The Nelder-Mead simplex optimization within the studied region suggested use of $6.5 \mathrm{M}$ ethanol and temperature of $0^{\circ} \mathrm{C}$ for maximal recovery of proteins (Figure 3 ).

3.2. Recovery Efficiency of Proteins from Starch Industry PFJ. The efficiency of the precipitation for recovery of active proteins from industrial PFJ was investigated using concentrate from the pilot evaporation. The precipitation was carried out at ethanol concentration of $10.4 \mathrm{M}$ and temperature of $+4^{\circ} \mathrm{C}$ due to practical reasons at the industrial site. 


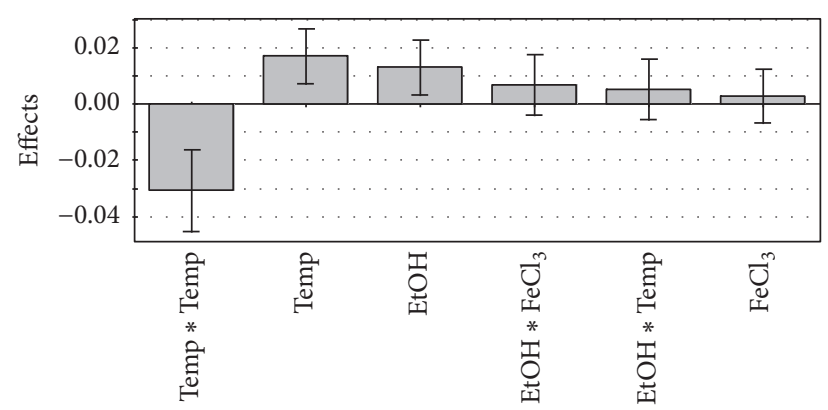

Figure 2: The effects of precipitation agents and temperature on recovery of resoluble proteins from potato. The scaled effects of the model terms are presented at $95 \%$ confidence level. Temp: temperature, EtOH: ethanol concentration, $\mathrm{FeCl}_{3}: \mathrm{FeCl}_{3}$ concentration, Temp * Temp: square term of temperature, EtOH $*$ $\mathrm{FeCl}_{3}$ : interaction term of ethanol and $\mathrm{FeCl}_{3}$, and $\mathrm{EtOH} * \mathrm{Temp}$ : interaction term of ethanol and temperature.

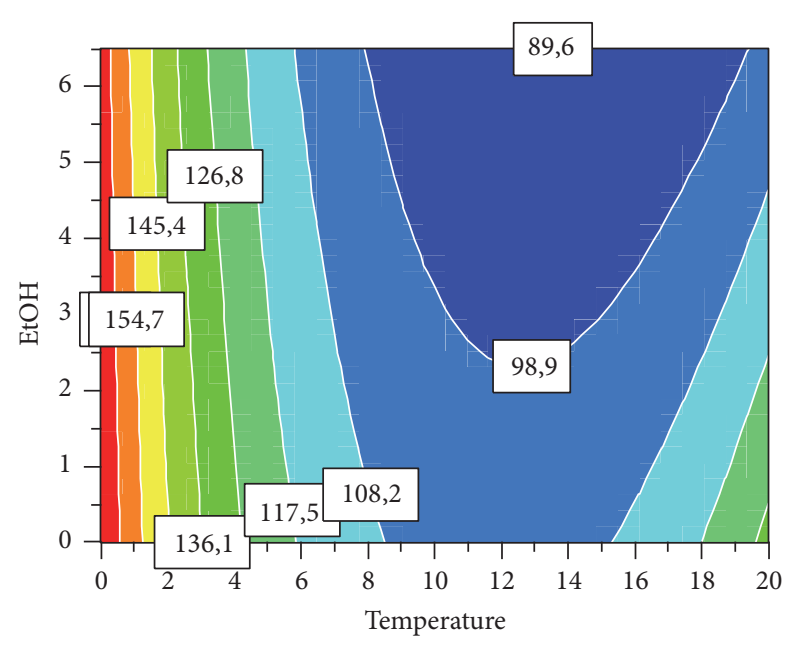

FIgURE 3: Prediction of favorable ethanol concentration and temperature within the investigated region to achieve highest possible quantity of resoluble proteins.

It can be observed in the SDS-PAGE (Figure 4) that both main protein fractions, PIs and patatin, were present in soluble form in the original PFJ feedstock. Evaporation did not seem to affect the quality of patatin $(39-45 \mathrm{kDa})$ or low molecular weight PIs (4-25 kDa), but some decrease in the band intensity is seen between 14 and $25 \mathrm{kDa}$. During the ethanol precipitation, the majority of patatin was precipitated irreversibly as only a minor quantity of patatin is present in the resolubilized fraction. PIs were divided into ethanol and precipitate and the majority of PIs could be recovered in ethanol or resolubilized from the precipitate.

According to the mass balance the total protein concentration in the original PFJ was $13 \mathrm{~g} / \mathrm{l}$ from which approximately $38 \%$ was left nonprecipitated in the ethanol phase (Table 3). The rest of the proteins were precipitated. Approximately $12 \%$ of the total protein was recovered by resolubilization from the precipitate (Figure 4 and Table 4). The activity

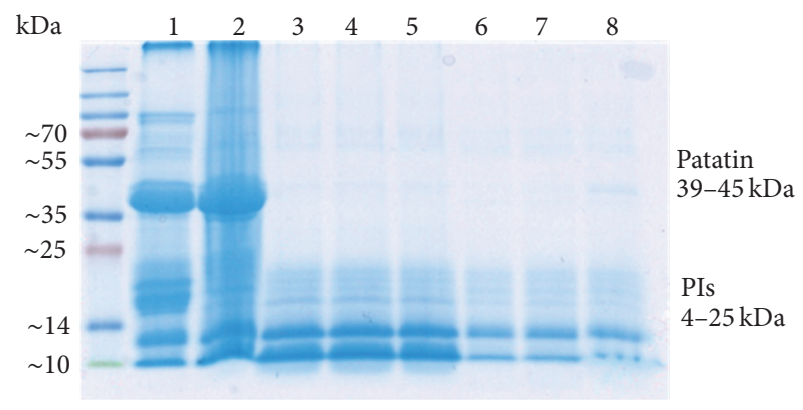

FIGURE 4: SDS-PAGE of proteins in native PFJ and its processed fractions. 1: PFJ; 2: concentrate; 3, 4, and 5: supernatant from precipitation with $10.4 \mathrm{M}$ ethanol (in triplicate); 6, 7, and 8: resolubilized protein in Tris buffer (in triplicate).

TABLE 3: Mass balance of total protein in the PFJ and its processed fractions.

\begin{tabular}{lcc}
\hline Fraction & $\begin{array}{c}\text { Protein } \\
\mathrm{g} / \mathrm{l}\end{array}$ & $\begin{array}{c}\text { Protein } \\
\mathrm{g} / \mathrm{kg} \text { of PFJ }\end{array}$ \\
\hline PFJ & 13 & 13 \\
Concentrate & 74 & 13 \\
Nonprecipitated (soluble) & 19.6 & 5 \\
Precipitated (resoluble) & 18.5 & 1.5 \\
Total soluble protein & & 6.5 \\
\hline
\end{tabular}

TABLE 4: Trypsin inhibition activity of native PFJ and processed concentrates.

\begin{tabular}{lcccc}
\hline Fraction & $x$ dil. & $\begin{array}{c}\text { Reaction } \\
\text { rate } \\
\text { abs/min }\end{array}$ & $\begin{array}{c}\text { Trypsin } \\
\text { inhibition } \\
\%\end{array}$ & $\begin{array}{c}\text { Relative } \\
\text { inhibition } \\
\text { /g protein }\end{array}$ \\
\hline Reference & - & 0.075 & 0 & - \\
PFJ & 10 & 0.007 & 91 & 9.3 \\
Concentrate & 60 & 0.016 & 79 & 8.5 \\
Nonprecipitated (soluble) & 8 & 0.012 & 84 & 11.9 \\
Precipitated (resoluble) & 20 & 0.008 & 89 & 5.4 \\
\hline
\end{tabular}

of resoluble PIs was confirmed by measurement of the trypsin inhibition activity (Table 4). The relative inhibition activity was calculated by dividing the activity by the quantity of total protein in the sample.

The trypsin inhibition activity per gram of protein was highest in the nonprecipitated fraction that remained after incubation in ethanol (Table 4). In this fraction patatin was present only in minor quantity. Some active PIs could also be recovered after precipitation by resolubilization. Altogether, the soluble fractions represent protein yield of $50 \%$ from total protein in PFJ, containing a major portion of active PIs and a minor fraction of patatin. The concentration of PFJ by means of low-temperature evaporation had a minor effect on trypsin inhibition activity. 


\section{Discussion}

The present research focused on development of an industrially feasible and energy-efficient process to recover active proteins from starch industry residues. At the beginning of this study the combination of ethanol and $\mathrm{FeCl}_{3}$ for precipitation was considered as the most feasible option for the purpose. It was, however, noticed that the use of $\mathrm{FeCl}_{3}$ did not improve the yield of soluble proteins at the examined conditions which may relate to conformational changes of PIs induced by $\mathrm{FeCl}_{3}$ [12]. Another disadvantage of $\mathrm{FeCl}_{3}$ and other salts is the need for their removal from produced protein fractions.

Based on the present results and previously reported investigations, ethanol precipitation allows satisfactory recovery of active PIs from PFJ [12]. Since ethanol can be recovered from the protein concentrate by means of low-temperature evaporation, principally using the same methodology compared to that in the concentration of PFJ, and circulated back to the precipitation process, we have considered it as the most feasible precipitation agent for the recovery of proteins in starch industry.

Regarding targeted purification of PIs, ethanol seems well suitable for maintaining high chymotrypsin activity while other agents may be considered for higher yield of trypsin inhibiting fraction of PIs [12]. However, to maintain overall feasibility of the procedure, we suggest that the use of other precipitation agents is considered only in case that their purification from the produced protein fractions can be arranged in a cost-efficient manner which reflects the benefit from improved active PI yield.

The yield of resoluble, potentially active, proteins was shown to depend on both ethanol concentration and precipitation temperature of which result is also in line with previous reports [11, 12]. Based on iterative optimization even higher ethanol concentrations and lower temperatures may be used than those actually investigated in the experiments. It was thus concluded that excess ethanol may be used in the pilot experiments to ensure sufficient precipitation and that the temperature should be as low as possible for efficient recovery. However, in the further process development it might be advisable to optimize the conditions for the precipitation with respect to the technoeconomic performance of the process.

The concentration of PFJ by means of low-temperature evaporation allowed a nearly 6 -fold concentration of potato proteins while only a minor decrease in the relative trypsin inhibition activity was detected. The proposed MVR evaporation technology is thus considered a feasible choice for the further process development. In the future investigations the overall feasibility evaluation of the concentration and precipitation process will be constructed.

\section{Conclusion}

Low-temperature evaporation and ethanol precipitation were successfully used for the recovery of active PIs from industrial PFJ. The evaporation, precipitation, and resolubilization procedure remained the trypsin inhibition activity of the PIs. The proposed process can be developed for an industrially feasible means for the treatment of starch industry waste waters.

\section{Disclosure}

The current address for Juho Järvinen is Danisco Sweeteners Oy, Sokeritehtaantie 20, 02460 Kantvik, Finland.

\section{Competing Interests}

The authors declare that there no conflict of interests regarding the publication of this paper.

\section{Acknowledgments}

This research was financed by the European Regional Development Fund (Project A32182), Finnish Funding Agency for Innovation (Project 553/31/2014), and University of Oulu, Chemical Process Engineering Unit. Cooperating starch manufacturer is acknowledged for the piloting opportunity and PFJ samples. Epcon Evaporation Technology AS and Oulu Water Alliance Ltd. are acknowledged for the pilot evaporation design and arrangements. Mrs. Lilja Tuohimaa is acknowledged for assistance in experimental.

\section{References}

[1] M. Ahokas, A.-L. Välimaa, T. Lötjönen, A. Kankaala, S. Taskila, and E. Virtanen, "Resource assessment for potato biorefinery: side stream potential in Northern Ostrobothnia," Agronomy Research, vol. 12, no. 3, pp. 695-704, 2014.

[2] V. Alt, R. Steinhof, M. Lotz, R. Ulber, C. Kasper, and T. Scheper, "Optimization of glycoalkaloid analysis for use in industrial potato fruit juice downstreaming," Engineering in Life Sciences, vol. 5, no. 6, pp. 562-567, 2005.

[3] V. Bártová and J. A. N. Bárta, "Chemical composition and nutritional value of protein concentrates isolated from potato (Solanum tuberosum L.) Fruit juice by precipitation with ethanol or ferric chloride," Journal of Agricultural and Food Chemistry, vol. 57, no. 19, pp. 9028-9034, 2009.

[4] S. Løkra, R. B. Schüller, B. Egelandsdal, B. Engebretsen, and K. O. Strætkvern, "Comparison of composition, enzyme activity and selected functional properties of potato proteins isolated from potato juice with two different expanded bed resins," LWT_Food Science and Technology, vol. 42, no. 4, pp. 906-913, 2009.

[5] G. A. Van Koningsveld, H. Gruppen, H. H. J. De Jongh et al., "Effects of $\mathrm{pH}$ and heat treatments on the structure and solubility of potato proteins in different preparations," Journal of Agricultural and Food Chemistry, vol. 49, no. 10, pp. 48894897, 2001.

[6] L. Pouvreau, Occurrence and physico-chemical properties of protease inhibitors from potato tuber: (Solanum tuberosum) [Ph.D. thesis], Wageningen Universiteit, 2004.

[7] S. Komarnytsky, A. Cook, and I. Raskin, "Potato protease inhibitors inhibit food intake and increase circulating cholecystokinin levels by a trypsin-dependent mechanism," International Journal of Obesity, vol. 35, no. 2, pp. 236-243, 2011.

[8] J. G. H. Ruseler-van Embden, L. M. C. Van Lieshout, S. A. Smits, I. Van Kessel, and J. D. Laman, "Potato tuber proteins 
efficiently inhibit human faecal proteolytic activity: implications for treatment of peri-anal dermatitis," European Journal of Clinical Investigation, vol. 34, no. 4, pp. 303-311, 2004.

[9] S. Mäkinen, J. Kelloniemi, A. Pihlanto et al., "Inhibition of angiotensin converting enzyme I caused by autolysis of potato proteins by enzymatic activities confined to different parts of the potato tuber," Journal of Agricultural and Food Chemistry, vol. 56, no. 21, pp. 9875-9883, 2008.

[10] A. Pihlanto, S. Akkanen, and H. J. Korhonen, "ACE-inhibitory and antioxidant properties of potato (Solanum tuberosum)," Food Chemistry, vol. 109, no. 1, pp. 104-112, 2008.

[11] V. Bártová and J. A. N. Bárta, "Chemical composition and nutritional value of protein concentrates isolated from potato (Solanum tuberosum L.) fruit juice by precipitation with ethanol or ferric chloride," Journal of Agricultural and Food Chemistry, vol. 57, no. 19, pp. 9028-9034, 2009.

[12] A. Waglay, S. Karboune, and I. Alli, "Potato protein isolates: recovery and characterization of their properties," Food Chemistry, vol. 142, pp. 373-382, 2014.

[13] L. Eriksson, Design of Experiments: Principles and Applications, MKS Umetrics AB, Malmo, Sweden, 2008.

[14] J. A. Nelder and R. Mead, "A simplex method for function minimization," The Computer Journal, vol. 7, no. 4, pp. 308-313, 1965.

[15] J. Bárta and V. Bártová, "Patatin, the major protein of potato (Solanum tuberosum L.) tubers, and its occurrence as genotype effect: processing versus table potatoes," Czech Journal of Food Sciences, vol. 26, no. 5, pp. 347-359, 2008. 


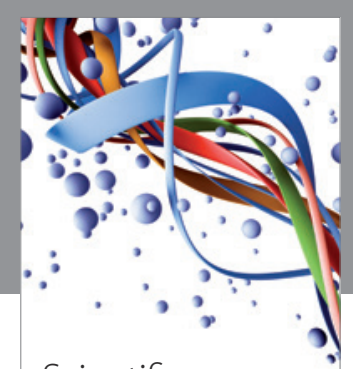

Scientifica
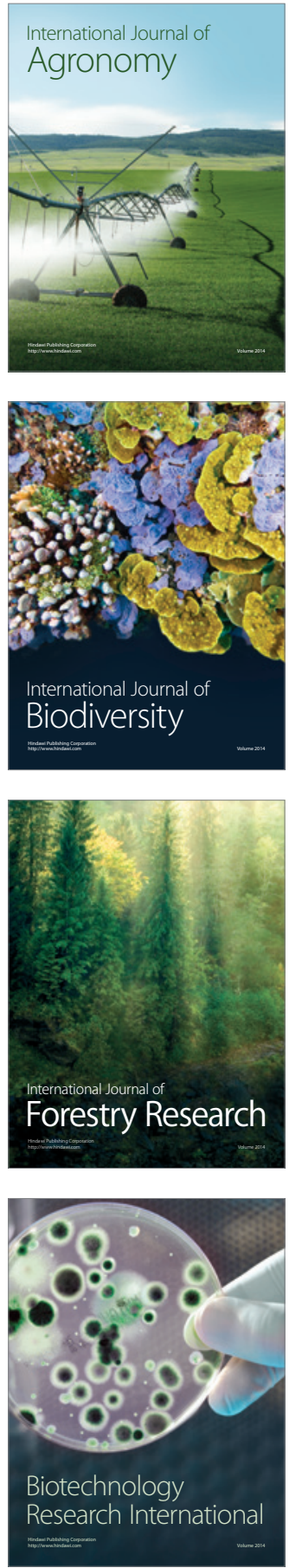
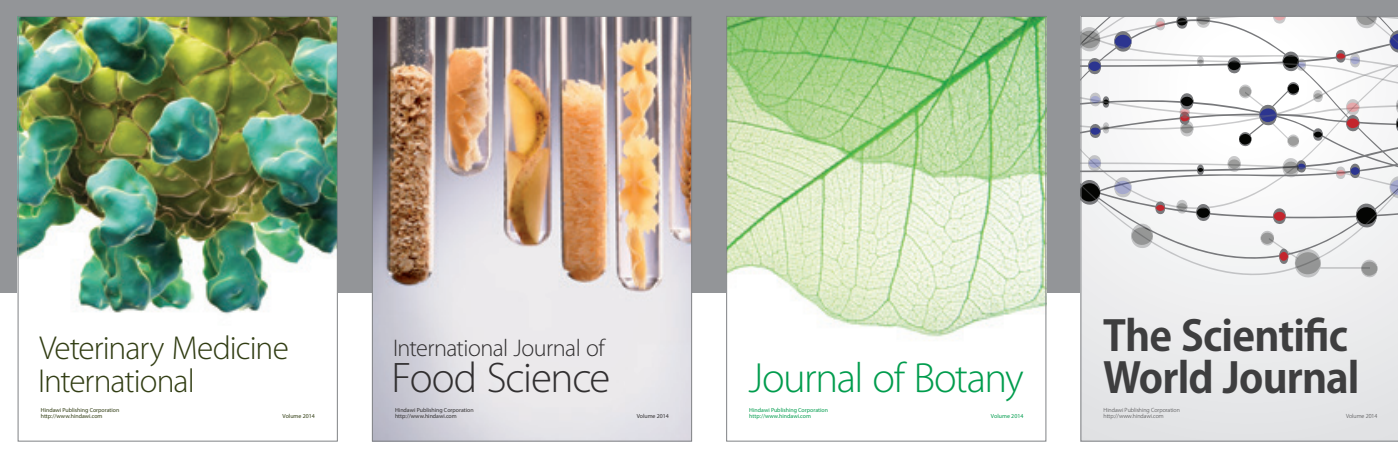

The Scientific

\section{World Journal}

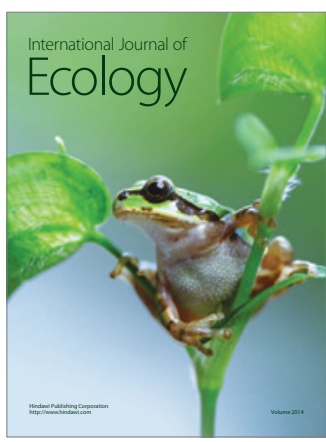

\section{Hindawi}

Submit your manuscripts at

https://www.hindawi.com
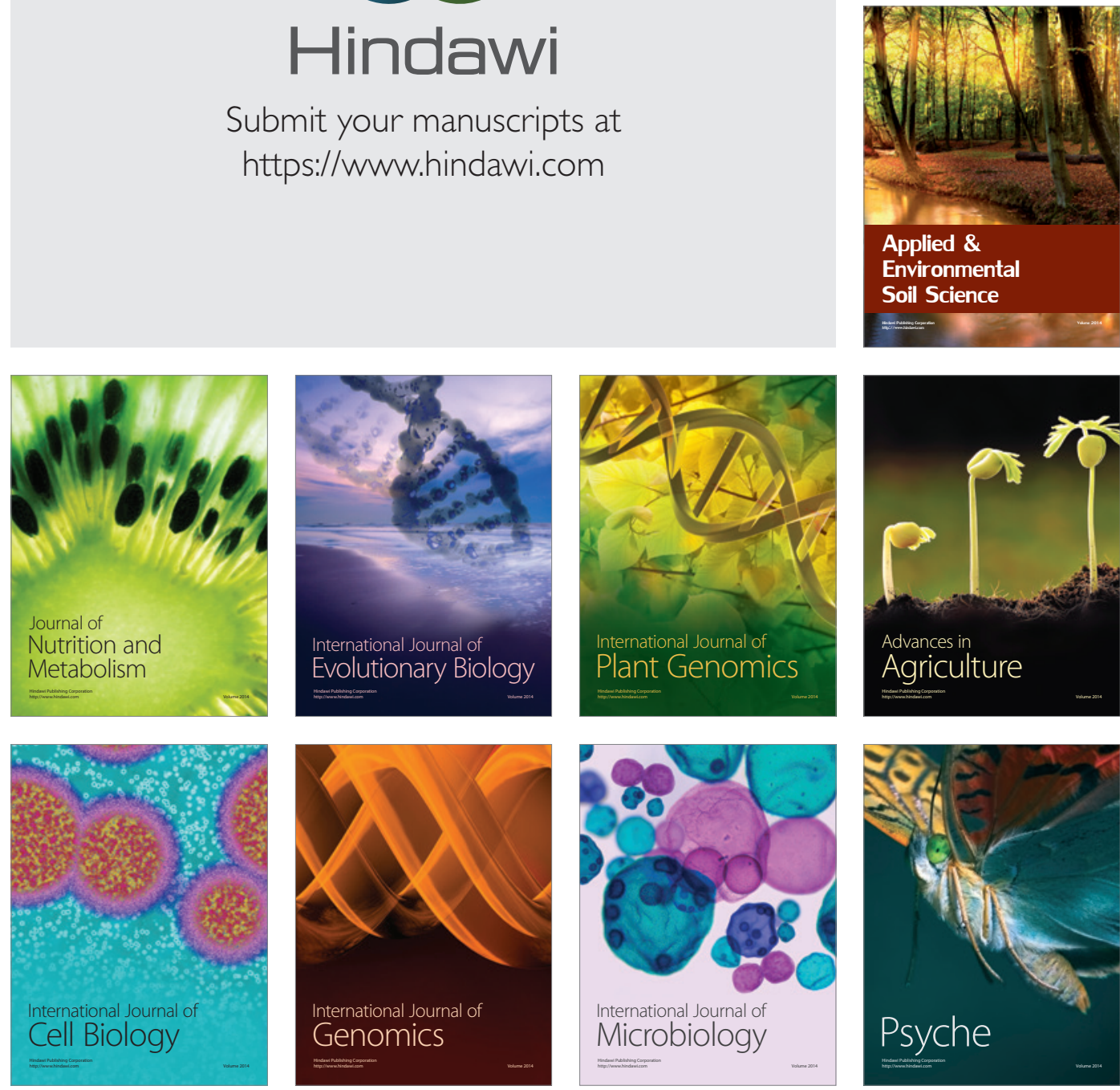
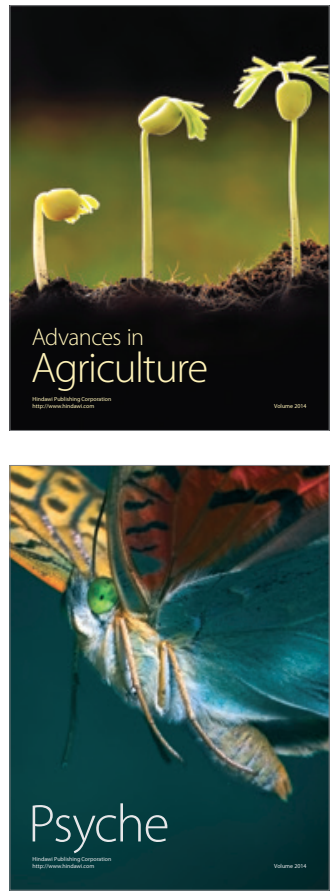